\title{
DORSAL LONGITUDINAL MYELOTOMY
}

By Ranjit K. Laha, M.D., Manuel Dujovny, M.D. and Carroll P. Osgood, M.D. Department of Neurological Surgery, University of Pittsburgh School of Medicine, and Veterans Administration Hospital, Pittsburgh, Pennsylvania

Abstract. An evaluation of dorsal longitudinal myelotomy in the management of spasticity of the lower limbs has been done in I 7 patients. The follow-up has varied from I month to over 2 years. Most patients achieved satisfactory relief from spasticity. Eight patients have died after the operation in chronic care hospitals. In all except one, the spasticity had been relieved. Eight out of the nine living patients have benefited from myelotomy. Recurrence of spasticity following the first operation occurred in four patients, two of whom improved after a repeat myelotomy. In the presence of fixed contractures of the hip and knee joints, a satisfactory clinical result may not be obtained after the myelotomy.

Key word: Longitudinal myelotomy.

\section{Introduction}

SPASTICITY associated with flexor spasms of the lower limbs may cause considerable annoyance to the patient and may pose a serious threat to nursing care. It also interferes significantly with rehabilitative goals in an already handicapped patient. Generally, various forms of drug therapy have been useless or have shown limited benefit (Monster et al., I973; Pederson, I974; Jonsson et al., 1975). Peripheral neurectomy (Freeman \& Heimburger, I947), myotomy, and tenotomy, also, have not been uniformly successful. Though rhizotomies, both posterior and anterior, and cordectomy have relieved spasticity, the resulting sensory deficit, muscle atrophy, or both, have been undesirable (Foerster, I913; Munro, 1945; Freeman \& Heimburger, 1947; Freeman \& Heimburger, I948; McCarty, I954). Similarly, the results of chemical rhizotomies have been inconsistent and unpredictable (Freeman \& Heimburger, I948; Cooper \& Hoen, I949; Kelley \& Gautier-Smith, I959; Davis, I975).

In I95I, Bischof described the technique of longitudinal myelotomy in the treatment of spasticity of the legs. Later, he modified his technique from a lateral to a posterior midline approach (Bischof, 1967 ). The operation involves separation of the anterior half from the posterior half of the spinal cord at TII-SI segments in the central grey, thereby interrupting the poly- and mono-synaptic reflex arcs as well as the collaterals of Kolliker.

We are reporting our experience with midline dorsal myelotomy in $\mathrm{I} 7$ patients. The follow-up has ranged from I month to over 2 years.

\section{Clinical Material}

All the patients reported in this series were male and their ages ranged from 20 years to 72 years. The aetiology of spasticity was multiple sclerosis in nine patients, injury to the spinal cord in five patients with injury to the cervical spine in two and thoracic spine in three, Huntington's chorea in two patients and syringomyelia in one. All the patients were referred from peripheral chronic care hospitals.

Please address reprints: Ranjit K. Laha, M.D., Department of Neurological Surgery, Veterans Administration Hospital, University Drive C, Pittsburgh, Pennsylvania 15240.

I $4 / 3-B$ 
None of these patients had any useful movements in his legs. The sensory examination was abnormal in most of the patients with total to partial sensory loss in the lower extremities. Except for two patients with ileal loops and three patients with condom drainage, all the rest had indwelling catheters. Preoperative cystometrograms were carried out in seven patients only. A small capacity spastic bladder was noted in five while the remaining two patients had flaccid bladders. Trochanteric or sacral decubiti were present in almost all cases. Most of the patients had been on various spasmolytic agents including dantrolene sodium without any benefit. A brief summary of clinical survey is presented in Table I.

TABLE I

\begin{tabular}{|c|c|c|c|c|c|}
\hline $\begin{array}{l}\text { Age } \\
\text { (yrs) }\end{array}$ & Diagnosis & $\begin{array}{l}\text { Sensory } \\
\text { loss }\end{array}$ & $\begin{array}{l}\text { Follow-u } \\
\text { (months) }\end{array}$ & $\begin{array}{l}\text { up } \\
\text { s) }\end{array} \underset{\text { spasticity }}{\text { Relief }}$ & Remarks \\
\hline 20 & Cervical cord trauma & Complete & I4 S & Satisfactory & $\begin{array}{l}\text { Required reoperation- } \\
\text { Dead }\end{array}$ \\
\hline $6 I$ & Thoracic cord trauma & Complete & $16 s$ & Satisfactory & Dead \\
\hline 39 & M.S. & Partial & $24 S$ & Satisfactory & Dead \\
\hline 50 & M.S. & Partial & $22 s$ & Satisfactory & Alive \\
\hline 56 & M.S. & Complete & $6 s$ & Satisfactory & Dead \\
\hline 26 & Cervical cord trauma & Complete & $27 s$ & Satisfactory & Alive, mild recurrence \\
\hline 53 & M.S. & Complete & $24 s$ & Satisfactory & Dead \\
\hline 72 & M.S. & Complete & $5 \mathrm{I}$ & Unsatisfactory & $\begin{array}{l}\text { Required reoperation- } \\
\text { Dead }\end{array}$ \\
\hline 49 & Huntington's chorea & ? & 25 & Satisfactory & Dead \\
\hline 29 & Thoracic cord trauma & Complete & $15 s$ & Satisfactory & Alive \\
\hline 52 & M.S. & Complete & I $S$ & Satisfactory & Dead \\
\hline $4 \mathrm{I}$ & Syringomyelia & Partial & $9 s$ & Satisfactory & Alive \\
\hline 49 & M.S. & Partial & 85 & Satisfactory & Alive \\
\hline 45 & Thoracic cord trauma & Complete & 75 & Satisfactory & Alive \\
\hline 55 & M.S. & Partial & 45 & Satisfactory & $\begin{array}{l}\text { Alive, required reope- } \\
\text { ration }\end{array}$ \\
\hline 45 & Huntington's chorea & $?$ & $3 \mathrm{I}$ & Unsatisfactory & $\begin{array}{l}\text { Severe contractions of } \\
\text { hip and knee-Alive }\end{array}$ \\
\hline 24 & M.S. & Partial & 25 & Satisfactory & Alive \\
\hline
\end{tabular}

\section{Operative Technique}

Under general endotracheal anaesthesia with the patient in prone or lateral position, a laminectomy is made from Tro to LI. After the dura mater is opened in the midline, the operative microscope is brought into the field and under Io $\times$ magnification, the arachnoid membrane is opened in the midline. The tip of the conus medullaris is visualised and the SI root (largest root) is followed into the spinal cord. The midline dorsal longitudinal vein and the pia mater are then coagulated with the low current bipolar coagulator starting from $S_{\text {I }}$ segment and proceeding cephalad to the emergence to TI I or TI 2 root. An incision $3 \mathrm{~mm}$ in depth is then made with a sharp knife or razor blade in the entire length of the spinal cord from TII or TI2 to SI level. The myelotomy knife is then inserted first on one side and myelotomy carried out longitudinally. The process is then repeated on the other side (fig. I). The myelotomy is then carefully inspected 


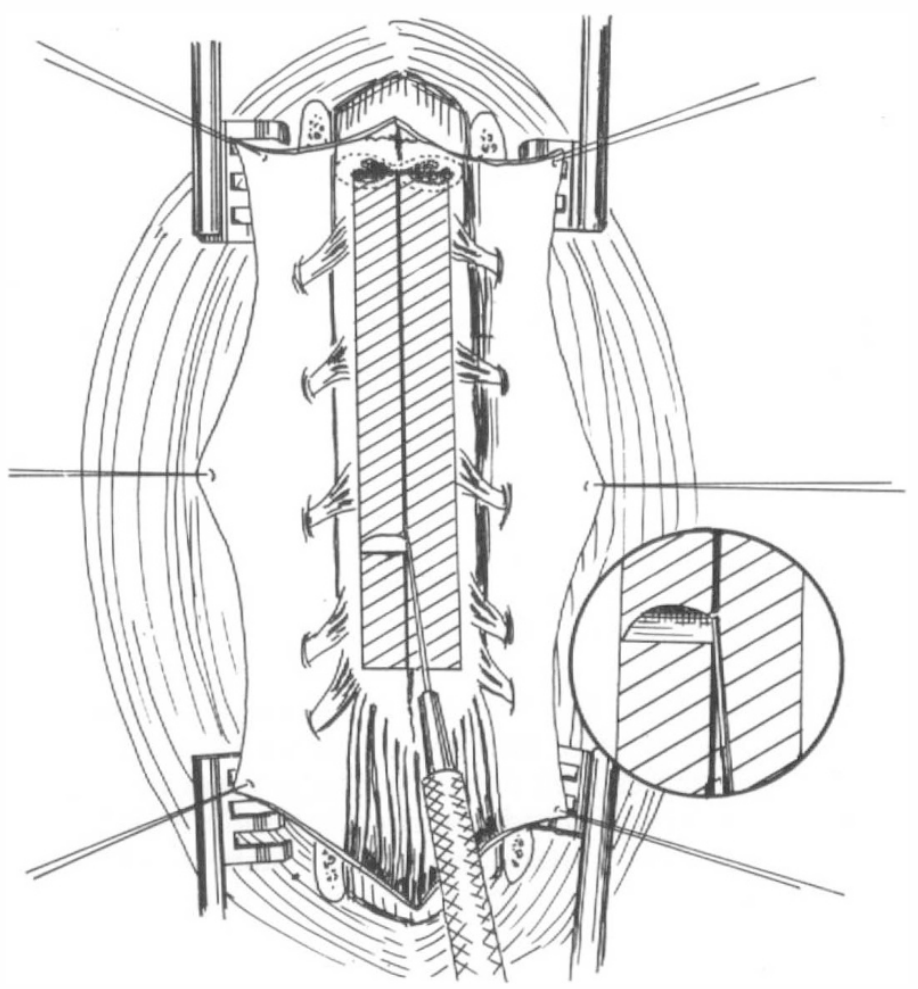

FIG. I

Shows the technique of myelotomy.

for its adequacy. The bleeding usually is minimal and can be easily controlled with gentle pressure. The dura mater is then closed.

\section{Results}

All patients had initial relief from spasticity except Cases I, 8 and I6. Persistence of spasticity on one side in Case I required repeat myelotomy a few months after the initial procedure with satisfactory results. In the interim period, chemical rhizotomy with absolute alcohol had been tried without success. In Case 8, reoperation was performed within 2 weeks of the initial procedure because of the unrelieved spasticity. Following the second operation, the hip contractions were partly abolished in this patient. The clinical result was considered unsatisfactory because of the unrelieved fixed contractures of the knees and the hip. Similarly, Case I6 was a failure because of the severe contractures of the hip and knee on the right side. A recent case (Case I5) was initially considered unsatisfactory as the spasticity returned soon after the operation. This patient was operated upon a second time with relief of spasticity, but the ankle jerks persisted, suggesting inadequate caudal extent of the myelotomy. Out of I 7 patients, eight have died from I month to 2 years after the operation. All except one of these patients were considered to have obtained satisfactory results. The cause of death was either renal failure, pulmonary infection, or septicemia in seven patients. One patient died of massive haemorrhage due to erosion of the internal carotid artery at the tracheostomy site. 
Seven patients had preoperative cystometrogram, a follow-up cystometrogram in the postoperative period was carried out in four patients. The bladder status was unchanged in three, whereas in one patient, the bladder had become flaccid from a spastic state. It was also noted that patients who had external catheters before had to have an indwelling Foley catheter for a few weeks after the operation. Later, the external drainage was re-established in all such patients.

The sensory loss was complete in nine patients. Five of these had injury to the spinal cord, with sensory level at $\mathrm{C}_{5}$ in two patients and at $\mathrm{T}_{9}, \mathrm{~T}_{4}$, and $\mathrm{T}_{3}$ in the remaining three patients. The other four patients had longstanding multiple sclerosis with asymmetric sensory levels in the mid-thoracic and thoracolumbar regions. The sensory examination was unreliable in the two patients suffering from Huntington's chorea because of their marked dementia. The remaining patients had partial preservation of sensation in the lower limbs.

\section{Discussion}

Over the years, a wide variety of surgical procedures have been used to control spasticity and flexor spasms of the lower extremities with variable results. The effect of posterior rhizotomy has been short lasting and disadvantageous as it increases the sensory deficit. The anterior rhizotomy advocated by Munro (1945) though relieving spasticity, leads to muscular atrophy and precludes permanently any future hope of recovery of motor function. Similarly, selective cordectomy (McCarty, 1954) has resulted in permanent destruction of functions of the spinal cord with abolition of reflex activities for bladder, bowel and erection. Since the description of a more physiological approach of relieving spasticity while retaining residual function by Bischof (195I, 1967) several authors have applied the technique with encouraging results (Tonnis \& Bischof, I962; Ivan et al., I967; Moyes, I969; VanderArk \& Kempe, I969; Laitinen \& Singounas, I97I; Yamada et al., I972; Davis, I975; Ivan \& Wiley, 1975).

Feurer et al. (1972) studied the anatomical and histological changes following longitudinal myelotomy in dogs. They noted interruption of the connection between the anterior and posterior horn cells. Considerable damage was noted in the posterior horn cells along with degenerative and regenerative changes in the anterior horn cells. They observed that normal dogs undergoing myelotomy became temporarily paraparetic, but regained walking ability within 2 weeks after surgery. Several experimental modifications of the original myelotomy technique have been performed by Ivan (1975) in an attempt to section the cord more precisely within the central grey matter.

We have followed the dorsal midline approach for its suggested advantages (Laitinen \& Singounas, I97I) especially its possible sparing of the connections between the pyramidal tract and the anterior horn cells. Preservation of the motor pathways may allow recovery of the motor function after myelotomy as was noted by Laitinen and Singounas (I97I). None of our patients, however, showed any improvement of volitional motor activity following the operation.

The persistence or recurrence of spasticity, following the first myelotomy, occurred in four of our patients. Subsequently, the myelotomy was repeated in three with satisfactory results in two of these cases. During reoperation, the myelotomy was extended cephalad in each case. The poor clinical results in the remaining two patients (Cases 8 and I6) were attributed to the presence of fixed contractures of the hip and knee joints. A resection of the joints in such cases may offer better results as has been suggested by Ivan and Wylie (1975). 
Several authors have noted preservation of residual sensory function postoperatively if such was the status prior to the operation (Tonnis \& Bischof, I962; Moyes, 1969). An increased impairment of sensation following operation has also been observed. In most cases, sensations have recovered spontaneously (Laitinen \& Singounas, I97I). In our cases with partial sensory loss, some preservation of sensation in the lower limbs was noted after the operation.

Tonnis and Bischof (1962) and others (Moyes, 1969; Laitinen \& Singounas, I97I; Davis, I975) have noted preservation or improvement of bladder functions following myelotomy. As can be seen in Table I, none of our patients improved significantly in bladder function following myelotomy. A deterioration of bladder function was noted in the immediate postoperative period in three of our patients who wore condom catheters. In these patients, a Foley catheter had to be used for a few weeks after the operation. Later, external drainage could be re-established. Others have also noted temporary worsening of the bladder function in the postoperative period with either recovery or permanent worsening (Moyes, I969; Laitinen \& Singounas, I97I). It has been suggested that a unilateral downward extension of the myelotomy from $S_{I}$ to $S_{5}$ segments may be done for a spastic bladder. This was not done in any of our cases. In one patient, however, a spastic bladder became flaccid about 2 weeks after the myelotomy.

Although our longest follow-up has been only a little over 2 years, we feel that dorsal longitudinal myelotomy is an effective measure in the management of severe spasticity of the lower limbs. In other series in which the patients have been observed for much longer periods, the flaccidity has been maintained (Tonnis \& Bischof, I962; Moyes, I969; Laitinen \& Singounas, I97I; Ivan \& Wylie, I975). The management of recurrent spasticity following myelotomy depends on its severity and, at times, the myelotomy may need to be repeated. In the presence of severe contractures of the joints, the myelotomy may not be successful in improving the condition of the patient.

\section{RÉSUMÉ}

Une étude de la myélotomie dorsale, longitudinale dans le traitement des états spastiques des extrémités inférieures a été entreprise chez 17 patients. Ils furent suivis durant une période post-opératoire variant d'un mois ä plus de deux ans. La plupart des malades beneficiërent d'une amélioration de leur spasticité. Dans les suites opératoires, huit patients sont decédes dans des institutions de soins chroniques. A l'exception d'un seul, ils étaient tous soulagés de leur état spastique. Huit des neuf survivants ont benéficié de la myélotomie. L'opération fut suivie de récidive chez 4 malades, dont deux furent améliorés par une seconde myélotomie. En présence de sévëres contractures de la hanche et du genou, la myélotomie peut ne pas entrainer un résultat clinique satisfaisant.

\section{ZUSAMMENFASSUNG}

Die dorsale longitudinale Myelotomie für die Behandlung von Spastizität der Beine wurde in 17 Patienten mit Nachuntersuchung von einem Monat bis über zwei Jahre ausgewertet. Die meisten Patienten erreichten befriedigende Linderung von der Spastizität. Acht Patienten sind nach der Operation in chronischen Krankenhäusern gestorben, aber in nur einem war die Spastizität nicht gelindert. Acht von den neun lebenden Patienten haben von der Operation einen guten Resultat erreicht. Spastizität ist in vier Patienten nach der ersten Operation wieder eingetreten. Zwei von diesen wurden nach einer zweiten dorsalen Myelotomie wieder gelindert. In der Anwesenheit von schwerer, fester Beugekontraktur des Hüften- oder Kniegelenks mag ein befriedigendes klinisches Ergebnis von der Operation nicht erricht werden.

Acknowledgement. Sincere thanks are expressed to the Department of Medical Illustration for their cooperation and to Mrs K. Morrison for the drawing. 


\section{REFERENCES}

Bischof, W. (I95I). Die longitudinale myelotomie. Zentralblatt fur Neurochirurgie, II 79-88.

BischoF, W. (1967). Zur dorsalen longitudinalen myelotomie. Zentralblatt fur Neurochirurgie, 28, I23-1 26.

COOPER, I. S. \& HOEN, T. L. (1949). Intrathecal alcohol in the treatment of spastic paraplegia. Fournal of Neurosurgery, 6, 187-189.

Davis, R. (1975). Spasticity following spinal cord injury. Clinical Orthopaedics, I12, 66-75.

Feurer, H., Horner, T. C., DeMyer, W. E. \& CAmpbell, R. L. (1972). Anatomical and histological lesions in Bischof's myelotomy in dogs. Surgical Forum, 23, 438-440.

FoERSTER, O. (I9I3). On indications and results of the excision of posterior spinal roots in man. Surgery, Gynecology and Obstetrics, 16, 463-474.

FREEMAN, L. W. \& HEIMBURGER, R. F. (1947). The surgical relief of spasticity in paraplegic patients: Anterior rhizotomy. Fournal of Neurosurgery, 4, 433-435.

FREEMAN, L. W. \& HEIMBURGER, R. F. (1948). The surgical relief of spasticity in paraplegic patients: Peripheral nerve section, posterior rhizotomy and other procedures. Fournal of Neurosurgery, 5, 556-561.

Ivan, L. P., PaINE, K. W. E. \& Hunt, T. E. (1967). Experience with Bischof's myelotomy. Canadian fournal of Surgery, 10, I9I-195.

Ivan, L. P. \& WILEY, J. J. (I975). Myelotomy in the management of spasticity. Clinical Orthopaedics, 108, 52-56.

Jonsson, B., LADD, H., AFZelius-Frisk, I. \& LindBuRg-Broman, A. (I975). The effects of Dantrium on spasticity in hemiplegic patients. Acta Neurologica Scandinavica, 5I, 385-392.

Kelley, R. E. \& Gautier-Smith, P. C. (1959). Intrathecal phenol in the treatment of reflex spasms and spasticity. Lancet, 2, I I02-I I05.

LAITINEN, L. \& Singounas, E. (I97I). Longitudinal myelotomy in the treatment of spasticity of the legs. Fournal of Neurosurgery, 35, 536-540.

MCCARTY, C. S. (I954). The treatment of spastic paraplegia by selective cordectomy. Fournal of Neurosurgery, II, 539-545.

Monster, A. W., Herman, R., Meeks, S. \& Mchenry, J. (I973). Cooperative study for assessing the effects of a pharmacological agent on spasticity. American fournal of Physical Medicine, 52, I63-I68.

MoYes, P. D. (1969). Longitudinal myelotomy for spasticity. Fournal of Neurosurgery, 3I, 6I5-6I9.

MunRo, D. (1945). The rehabilitation of patients totally paralyzed below the waist: Anterior rhizotomy for spastic paraplegia. New England fournal of Medicine, 233, 453-46r.

Pederson, E. (I974). Clinical assessment and pharmacologic therapy for spasticity. Archives of Physical Medicine and Rehabilitation, 55, 344-354.

TonNis, W. \& Bischof, W. (I962). Ergebnisse der lumbalen myelotomie nach Bischof. Zentralblatt fur Neurochirurgie, 23, I20-132.

VANDERARK, G. D. \& KEMPE, L. G. (I969). Longitudinal myelotomy in spastic paraplegia. Military Medicine, 134, 608-61 I.

YAMADA, W., Mitchell, O.C. \& HARGEST, T. S. (I972). Evaluation of Bischof's myelotomy for control of mass spasms. In Present Limits of Neurosurgery, I. Fusek and Z. Kunc (editors). European Congress of Neurosurgery. Avicenum, Czechoslovak Medical Press, Prague, 1972, pp. 543-544. 